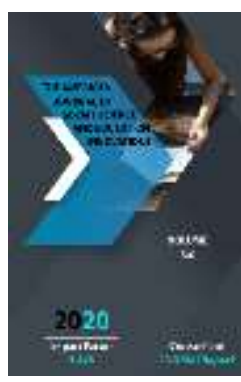

\section{Tent Of The Emir Of Bukhara (Second Half Of The 19th Century) ( History Of One Exhibit From The Collection Of The State Hermitage)}

Dilafruz Kurbanova

Doctor Of Historical Sciences Vice-Rector For Research And Innovation Of The National Institute Of Art And Design Named After Kamoliddin Behzod, Uzbekistan

Journal Website:

http://usajournalshub.c om/index,php/tajssei

Copyright: Original content from this work may be used under the terms of the creative commons attributes 4.0 licence.

\title{
ABSTRACT
}

This article is dedicated to a single artifact of the 19th century, tent of Emir of Bukhara, which is stored in the collection of the State Hermitage.

\section{KEYWORDS}

Spiritual and material development, museum-city, chodir, pandjara, State Hermitage, traditional summer houses, pyramidal “domes”.

\section{INTRODUCTION}

Bukhara, one of the ancient cities of the world, has been greatly contributing to the spiritual and material development of the humanity for centuries. It is no coincidence that it is called a museum-city.

It is one of the centres of the international tourism, which contains more than 400 archaeological and architectural monuments including 11 architectural ensembles, 8 mausoleums, 47 mosques, 14 caravanserais, 39 madrasahs, 8 archaeological monuments, 250 residential houses, 32 monumental art objects under the state protection. 
THE MAIN RESULTS AND FINDINGS

About a world-wide recognition of the cultural heritage of the city says a fact that the city, as well as the Pyramids of Egypt, historical centre of Rome, the Acropolis of Athens, the Kremlin of Moscow and Khiva, was included in the list of World Heritage objects in December 1993 by the Decree of the UNESCO, and in 1997 the $2500^{\text {th }}$ anniversary of Bukhara was celebrated under the aegis of the UNESCO'.

Unique artworks and productions, manuscripts of the scholars of Bukhara spread the world through the routes of the Great Silk Roads, on one of the main intersections of which the city is located. Today the antiques of Bukhara are adorning the expositions of the largest museums of the world in the cities such as Rome, Paris, Washington, Stockholm, Berlin, Istanbul, St. Petersburg, Moscow and etc.

State Hermitage is one of the greatest museums of the world. Universal and national significance turned it to be one of the most valuable objects of the cultural heritage of Russia.

Hermitage is one of the richest encyclopedic museums of the world. Its collection includes more than three million exhibits: over 16 thousand paintings, 12 thousand sculptures nearly 300 thousand works of applied arts, over a million coins, medals, orders, as well as a great number of arms and weapons, banners, books, scientific instruments and tools. It seems as if the whole history of the world culture, beginning from the lithic age until the modern history, revived on the walls of this museum.

The monuments, related to the arts of the nations of Central Asia (fourth millennium BC $20^{\text {th }}$ century) and the Caucasus $\left(10^{\text {th }} B C-19^{\text {th }}\right.$

\footnotetext{
1 "Bukhara State architectural-art museumconservation". - Tashkent, 2004.
}

centuries), occupy significant place in the collection of the museum².

Tents were the traditional summer houses in Central Asia, prosperous townspeople used to set them in the yards of their houses. It is known that there was a block of hereditary craftsmen in pre- revolutionary Bukhara who sew garden tents - chodir. As the tents were used intensively, few of them remained to this day: One of them is being exhibited in Samarkand museum in Uzbekistan, another was purchased by V. Rikmerski in Bukhara at the end of the $19^{\text {th }}$ century and now is at the Berlin museum of Ethnography. Side walls of the tents are kept at the funds of the Russian ethnographical museum. All remained samples are one-domed, with a coarse cotton cloth in the external side and appliqué in the internal.

Among the exhibits decorated with embroidery, which are kept in the Oriental department of the State Hermitage, an exclusive place is given to the tent (pavilion) which was bestowed on the emperor Alexander the Third by next to last emir of Bukhara Abdulakhad-khan (1885 - 1910) during his visit to St. Petersburg (1893?). There is no information about the installation of the tent in St. Petersburg, it is only known that it was exhibited at the Petrograd Stable museum in St. Petersburg in the twenties.

The tent represents the best and to a great extent unique sample of similar items. Thanks to its planning and the presence of rooms for different purposes it is similar to an enclosed house with a shed and inner yard. Unlike other remained samples, its both outer and inner sides are decorated with silk and appliqué.

Nearly square proportion of the tent is formed by four long walls, in the centre of one of which is the entrance. The inner space contains two intercommunicating square rooms on the right

\footnotetext{
2 "State Hermitage" guide-book. - p -2, St. Petersburg, 2010. - 35-125 pp.
} 
and left side of the entrance ant the inner yard partly covered with a shed. Two adjoining rooms opposite the entrance are richly decorated with insets from a Shakhrisabz appliqué and a gold embroidery panels. Three walls have long narrow sheds and the entrance has a separate small shed outside.

Two of the six windows are inner ones, and are directed to the inner yard.

The tent consists of seventeen parts: eight vertical walls, three pyramidal "domes", one of which is triple; six sheds. Twelve wooden poles, to which the outer sheds were installed, didn't remain to this day. Each wall is divided into sections, the borders of which are determined by sewn wooden poles, and between them there are wooden bars of the structure sewn in the layers of the cloth in the distance of $50-75 \mathrm{sm}$. Both ends of the wooden bars are sheathed in leather, at the bottom them there is a loop for the peg, and at the top there is a wooden button.

"Domes" of the hermitage tent, which have square bases, have a wooden structure consisting of four poles which are sewn diagonally in the square; in the corners which are reinforced by leather, there are openings for fixing the side walls to the supports; and at the perimeter there are a row of the loops for buttoning the side walls for fixing the structure. The outer part of the "domes" are decorated with striped silk, the inner part corresponds to the decoration of the side wall of that particular room.

Long outer sheds have one loop for buttons and openings for the poles of the frame of the sidewalls, on the other side they have openings for separate poles. The outer side of the sheds has striped silk and the inner side - patterned silk. Three right-angled sheds are made from

\footnotetext{
1"East and West: the art of the islamic world". - State Hermitage, St. Petersburg, Slavia, // Catalogue of the exhibition, 2011.
}

striped silk on the outer side, and covered with solid embroidery in the inner side 1 .

Main decorative design of the walls includes horizontal stripes of the ornaments scattered at the upper and lower parts of the walls, which are made in the method of the appliqué from cotton cloth. The patterns of the arches, where are either appliqués of the stylized images of the flower bunches or insertions from silk, are repeated in the central part between the sewn poles of the framework

Such kind of arches and niches with arched framing are typical for the rooms of rich townspeople; Dishes were kept in the niches, sometimes a bouquet of flowers was drawn on their walls. Construction of the windows made from cotton is also borrowed from monumental architecture. Up to now one can see plaster window grille - pandjara with clear geometrical image in old buildings. Thus, traditional architectural methods are continued in the decoration of the tent, only they are done by using unusual material textiles.

Markings and remains of the paper labels with the names of the russian manufactures and the surnames of the owners were conserved on the cotton cloth. On one of the appliqué there is a trademark «Фабрика торгового дома братьев М. и И.Щербаковых в Коломенском уезде» ("Brothers $M$ \&l Scherbakovs' trading house factory in the Kolomne uyezd"). It indicates the strengthening of the commercial relations between Russia and Central Asia in the eighties of the $19^{\text {th }}$ century once more.

\section{CONCLUSION}

It can be stated with confidence that the hermitage tent is a unique sample of "textile architecture" both for its construction and its 
The American Journal of Social Science and Education Innovations (ISSN - 2689-100x)

Published: December 25, 2020 | Pages: 180-183

Doi: https://doi.org/10.37547/tajssei/Volume02Issue12-31

wealth of décor. Quite likely, the tent was manufactured according to the special order of the emir's court as a present. Therefore, there were used unusual for this class of products types of the textile techniques - solid embroidery and gold embroidery, which demonstrate all diversities and beauty of the traditional handicraft.

\section{REFERENCES}

1. "Bukhara State architectural-art museumconservation". - Tashkent, 2004.

2. "State Hermitage" guide-book. - p -2, St. Petersburg, 2010. - 35-125 pp.

3. "East and West: the art of the islamic world". - State Hermitage, St. Petersburg, Slavia, // Catalogue of the exhibition, 2011.

4. Kurbanova, D. A. (2016). ANCIENT PEARLS IN GREAT WORLD MUSEUMS WHICH BELONG TO THE HISTORY OF UZBEKISTAN AND LEARNING THEM. Социосфера, (3), 55-61.

5. 5.Kurbanova, D.A. (2015). About the history of applied art of Uzbekistan in the nineteenth century and about the items of the State Museum of Art of the Peoples of the East of the Russian Federation. Young Scientist, (10), 1513-1515.

6. Rustamiy, S., Lutfullaeva, D., \& Gulomova, H. (2020). THE IMPORTANCE OF BALAGHA SCIENCE IN AESTHETIC EDUCATION. PalArch's Journal of Archaeology of Egypt/Egyptology, 17(6), 8882-8886.

7. Kurbanova, D.A. (2015). TO THE QUESTION ABOUT OBJECTS SUMMARIZING THE ANCIENT HISTORY OF UZBEKISTAN, PRESERVED NOW IN THE MUSEUM OF ANTHROPOLOGY AND ETHNOGRAPHY PETER THE GREAT (KUNSTKAMERA) OF THE RUSSIAN FEDERATION. Fundamental and applied research in the modern world, (105), 42-46.

8. Rustamiy, S. A. (2020). Content of components of the science balagat. ACADEMICIA: An International Multidisciplinary Research Journal, 10(10), 1332-1337.
9. Rustamiy, S. (2020). MAHMUD KOSHGARIY'S VIEWS ON FONETIC, GRAPHIC AND MORPHOLOGICAL CHARACTERISTICS OF TURKIC LANGUAGES. The Light of Islam, 2020(2), 37-44.

10. Rustamiy, S. A. (2019). Poetical art of Yusuf Balasagun. ISJ Theoretical \& Applied Science, 09 (77), 256-259.

11. Abdurashidovna, K. D. (2020). DAVID FOUNDATION AND COLLECTIONS OF THE $X$ CENTURY OF UZBEKISTAN AND THEIR SPECIFIC FEATURES. Crossroads of Culture, 4 (2).

12. Rustamiy, S. ART OF WORD AND ARTISTRY OF ARABIC PROVERBS.

13. Anvarovna, N. M., \& Karimullayevna, S. D. (2020). scientific and theoretical content of the science of balāğat. Journal of Critical Reviews, 7(6), 132-137.

14. Karimov, N.R. (2017). SCIENTIFIC HERITAGE OF KHAKIM TIRMIZI AND RESEARCHES OF HIS WORK "KHATM-ULAULIA" ("SEAL OF THE FRIENDS OF GOD"). In EUROPEAN RESEARCH (pp. 2427). 